clause favouring freedom of religious worship and expression.

It was evident to those who had attended previous Congresses, as well as the present, that distinct progress had been made. The Congress is now well established and able to draw support from the most influential persons in the country. Moreover, a growing cohesion among its members was noted, and it is safe to predict that some years hence a mesting of the Congress on a far greater scale might be held. There would necessarily be a meeting of the present belligerents to settle the terms of peace between them. After this limited conference, a more general conference would probably follow at which representatives from most of the peoples of the world would assemble to decide upon the future political structure of the New World Order, whether a reformed League of Nations or some type of federation. This would be an opportunity which should be seized. The World Congress of Faiths should organize a meeting of the most prominent representatives of all the great world religions to devise means by which the political New World Order may be given that spiritual drive and that steady and sustained spiritual support without which it can never endure. Annual meetings of the Congress will be held as heretofore; but the greater meeting some years hence will be the goal towards which they will deliberately be made to tend.

\section{MATHEMATICAL PROBLEMS IN SEISMOLOGY}

A BLAKE has recently directed attention to many A. outstanding problems in mathematical seismology (Trans. Amer. Geophys. Union, 1940). The following problems are, more particularly, mentioned : (1) Problems in the theory of seismic waves due to inhomogeneities in the media and other causes. and to new methods available for the study of the interior of the earth. (2) Problems of instrumental seismology including the new strain meter and rotation seismograph. (3) Problems relating to the complexities encountered in determining the response of engineering structures to the motion of a strong near earthquake. (4) Problems of statistical seismology, especially the periodicity problem. In many cases Blake states that seismological calculations may be performed by machines such as the differential analyser and punched card machines.

Concerning strong-motion problems, Blake says that the analysis of the response of a structure into characteristic or normal components satisfying linear equations depends on the treatment of the strainenergy function as quadratic. But the purpose of investigating the response to destructive earthquake motions requires consideration of strains much exceeding the limits within which Hooke's Law remains valid. According to the author the linear theory can then only be used as a first approximation and the effects of the various components of ground motion cannot be treated separately. The Rayleigh dissipation function may be important, but the case of small damping including the existence of normal modes of oscillation has been encountered in the case of buildings, bridges and tank towers. The paper will act as a signpost towards further progress in mathematical seismology.

\section{APPOINTMENTS VACANT}

Applications are invited for the following appointments on or before the dates mentioned :

Teacher of Generat Soience SubJects (Physics and Chemistry) AND A Teacher of Mathematics-The Principal, Luton Technical College, Park Square, Luton (August 9).

DieTrTian-The Secretary-Superintendent, Middlesex Hospital, London, W.1 (August 9).

Assistant INSPECTOR OF Schoors-The Education Officer, Education Office, Katharine Street, Croydon (endorsed "Assistant Inspector of Schools") (August 11).

Assistant Secretary FOR EDUcation-The Secretary for Education, Education Otfices, 6 Lampton Road, Hounslow, Middlesex August 23)

Collage Librarian-The Secretary, Bedford College for Women, Regent's Park, London, N.W.1 (September 13).

Professor of MATHeMatics-The Registrar, University College of Swansea, Singleton Park, Swansea (September 13).

PART-TIME LEOTURERS AND INSTRUCTORS IN ALL SUBJECTS OF MECHANICAL, ELECTRICAL AND PRODUCTION ENGINEERING-The Principal, South-West Essex Technical College and School of Art,
Forest Road, Walthamstow, London, E.17.

\section{REPORTS AND OTHER PUBLICATIONS}

(not included in the monthly Books Supplement)

\section{Great Britain and Ireland.}

John Innes Horticultural Institution. Thirty-first Annual Report for the Year 1940. Pp. 20. (London: John Innes Horticultura1

The British Council. Report for 1940-1941. Pp, 176. (London. The British Council.)

$[217$

Transzations of the Hertfordshire Natural History Society. Vol. 21, Part 3: Sawflies of the Berkhamsted District, with a List of the Sawflies of Hertfordshire and Buckinghamshire, and a Survey of the 177-232. (Hertford: Stephen Austin and Sons, Ltd.) 5s.
[217

\section{Other Countries}

Report and Accounts of the National Botanic Gardens of South Africa, Kirstenbosch, Newlands, Cape (and the Karoo Garden, Whitehill, near Matjesfontein) for the Year ending 31st December 1940. Pp. 20. (Kirstenbosch: National Botanic Gardens.) [147] Contributions from the Biological Laboratory of the Science Society of China, Zoological Series. Vol. 13, No. 9: Study of the Effect of Cerebral Cortical Lesion on the Respiratory Exchange and its Associated Phenomena of the Albino Rat (Mus norvegicus) By Y. J. Wu, T.L. Chiu and C. Ping. Pp. 101-120. 40 cents. Vol. 13, No. 10: On the Digestive Enzymic Actions in the Gut of the Earthworm, Pheretima. By Y. Chiung Puh. Pp. 121-134. 80 cents. Vol. 14: Taxonomy and Faunal Relations of the Iimnitic Oligochæta of China. By Y. Chen. Pp. 132. 13 dollars. Vol. 15, Part 1: Study of some Forest Insects of Nanking and its Vicinity, Part 4: Observations on the Pine Moth (Dendrolimus punctata Walker). By C. P. Miao. Pp. 16. 80 cents. Vol. 15, Part 2: Compounds related to the Natural Oestrogens: $\gamma$-Cyclopentyl- $\delta$-(4-Hydroxyphenyl)- $\Delta \gamma$-Hexene, $\gamma-(2-$ Minton. Pp, 17-28. (Shanghai: Science Society of China.) HuangReport of the Aeronautical Research Institute, Tôkyô Imperial Report of the Aeronautical Research Institute, Tôkyô Imperial
University. No. 204: Numerical Calculation of Power Variation with University. No. 204 : Numerical Calculation of Power Variation with By Keikichi Tanaka, Osamu Tamura and Osamu Konisi. Pp. 32. 50 sen. No. 205: On the Subsonic Flow of a Compressible Fluid p sst a Symmetrical Joukowski Aerofoil. By Susumu Tomotika and Hazimu Umemoto; Pp. 33-126. 1.30 yen. (Tôkyô: Kôgyô Tosho Kabushiki Kaisha.)

Report of the Institute of Scientific Rescarch, Manchoukuo. Vol. 4, Nos. 19-20: On the Fatty Oil of Awa (Starica itarica, Beauv.) Bran., by Mano Yoshikatsu; On the Vitamin Contents of Dried Mishrooms produced in Manchoukuo, by Kozo Kawakami and Hideo Miydyoshi. Pp. 333-404. (Hsinking: Institute of Scientific Research.) 25 sen.

Baltische Geodätische Kommission. Sonderveröffentlichungen, Nr. 8: Messung der Grundlinien Örebro und Värnamo in Schweden im Jahre 1938. Von U. Pesonen. Pp. 26. Sonderveröffentlichungen Nr. 9: Tafeln zur tbertragung geographischer Koordinaten auf dem Internationalen Erdellipsoide im Bereich $35^{\circ}$ bis $71^{\circ}$ Breite. Pp. 54. ((Helsinki : Baltische G todätische Kommission.)

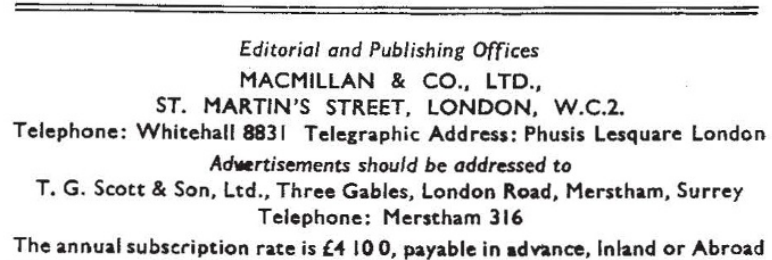

The annual subseription rate is $\$ 4100$, payable in advance, Inland or Abroad 